\title{
Correlation between Individual Characteristics and Workload toward Occupational Stress of Social Undesirables Facilitators
}

\section{Hubungan antara Karakteristik Individu dan Beban Kerja dengan Stres Kerja pada Pendamping Penyandang Masalah Kesejahteraan Sosial}

\author{
Siti Anisah, Mulyono \\ Department of Occupational Safety and Health, Faculty of Public Health Universitas Airlangga \\ Campus C Mulyorejo, Surabaya, East Java 60115 Indonesia
}

\begin{abstract}
Introduction: Prevalence occupational stress continues to increase. Based on survey in 2012, there was $64 \%$ workers in Indonesia suffered increased stress compared to previous year. According to the Great Britain 2017 statistics, jobs with higher than average rates of stress are health workers and social workers. Several factors that can affect occupational stress are individual characteristics and workload. The aim of this study is to analyze the relationship of individual characteristics (age, sex, education level, and working period) and workloads (physical and mental workloads) toward the level of occupational stress of social undesirables facilitators at Regional Technical Implementation Unit Social Shelter Keputih Surabaya. Methods: This study was observational research and used cross-sectional method. Sample in this research was 21 workers. The sample were taken used total sampling. The writer used contingency coefficient for analyzing variables relation. Results: The study showed the age (coefficient $=0.572$ ) and mental workload (coefficient $=0.420$ ) had a moderate relation toward occupational stress level. Sex (coefficient $=0.136$ ) had the lowest relation toward occupational stress level. The education level (coefficient $=0.398)$, working period $($ coefficient $=0.298)$, and physical workload $($ coefficient $=0.209)$ had a low relation toward occupational stress level. Conclusion: The individual characteristic (age) and workload (mental workload) related to occupational stress.
\end{abstract}

Keywords: individual characteristics, occupational stress, workload

\begin{abstract}
ABSTRAK
Pendahuluan: Tempat penyortiran dan penimbangan daun bawang merupakan sebuah tempat usaha sektor informal yang bPendahuluan: Jumlah stres kerja terus mengalami peningkatan. Berdasarkan survei pada tahun 2012 sebanyak 64\% pekerja di Indonesia mengalami peningkatan stres dibandingkan tahun sebelumnya. Menurut data statistik Great Britain 2017, pekerjaan yang paling berisiko mengalami stres kerja adalah tenaga kesehatan dan pekerja sosial. Beberapa faktor yang dapat mempengaruhi stres kerja adalah karakteristik individu dan beban kerja. Tujuan penelitian ini adalah untuk menganalisis hubungan antara karakteristik individu (usia, jenis kelamin, tingkat pendidikan, masa kerja) dan beban kerja (beban kerja fisik, beban kerja mental) dengan tingkat stres pada pendamping Penyandang Masalah Kesejahteraan Sosial (PMKS) di Unit Pelaksana Teknis Dinas (UPTD) Lingkungan Pondok Sosial (Liponsos) Keputih Surabaya. Metode: Penelitian ini bersifat observasional dengan desain studi cross-sectional. Sampel penelitian berjumlah 21 orang dan teknik pengambilan sampel menggunakan total sampling. Analisis kuat hubungan antar variabel menggunakan contingency coefficient. Hasil: Hasil uji statistik menunjukkan bahwa usia (koefisien= 0,572) dan beban kerja mental (koefisien= 0,420 ) memiliki tingkat hubungan sedang dengan stres kerja. Jenis kelamin (koefisien $=0,136$ ) memiliki tingkat hubungan sangat rendah dengan stres kerja. Tingkat pendidikan (koefisien= 0,398 ), masa kerja (koefisien $=0,298$ ), dan beban kerja fisik (koefisien= 0,209) memiliki tingkat hubungan rendah dengan stres kerja. Simpulan: Karakteristik individu (usia) dan beban kerja (beban kerja mental) berhubungan dengan stres kerja.
\end{abstract}

Kata kunci: beban kerja, karakteristik individu, stres kerja

Author for Correspondence:

Siti Anisah

Email: siti.anisah-2016@fkm.unair.ac.id

Telephone: +6283856906683

(C2020 IJOSH All right reserved. Open access under CC BY NC-SA license doi: 10.20473/ijosh.v9i1.2020.12-20 Received January 10, 2019, received in revised form January 21, 2019, Accepted April 13, 2020, Published: April 2020 


\section{INTRODUCTION}

Workload and work capacity are two factors that should be balanced for resulting optimal performance in work. Workload which is not balanced with work capacity leads to a decrease in performance, such as causing occupational stress. Individual characteristics, one of the components of work capacity, have several aspects namely age, sex, education level, and working period. The result of the research conducted by Lestari, Wahyuni and Ekawati (2015) shows age, sex, and working period cause occupational stress toward the Wardens of Class IIA Women in Semarang. The individual characteristics in a workplace have potency in causing occupational stress.

Workload refers to the ability of an individual's body to do work. The workload is divided into physical workload and mental workload. Physical workload refers to the amount of physical work done by someone such as pushing, lifting, pulling, and dropping. On the other hand, mental workload is a work activity that involves more thoughts and feelings. Even though mental activity seems lighter than physical work activity, it has heavier responsibility than physical activity because it involves the work of brains than working muscles. Each workload received by employers should be appropriate to their physical abilities, cognitive abilities, and limitation (Tarwaka, 2013). Workload which is whether too low or high causes a decrease in productivity and leads to occupational stress. According to the research conducted by Hasan, Wahyuni and Kurniawan (2018) showed there was relationship between mental workload toward occupational stress of workers at Cental Control Room in PT. PJB Paiton Probolinggo. Stress is a human reaction due to forces or requirements. If stress can be properly controlled, it will be a positive thing. In contrast, if stress cannot be controlled, it will cause a decrease in performance and health disorder (Wu and Shih, 2010).

According to the Great Britain 2017 statistics, jobs with higher than average rates of stress are health workers and social workers. One type of social workers is social undesirables facilitators. Social undesirables facilitators in Regional Technical Implementation Unit Social Shelter Keputih Surabaya have responsibilities for helping doing Activities of Daily Living (ADL) such as bathing, helping to wear clothes, preparing meals, distributing meals, cleaning leftover food, providing medicine, preparing medicine, cutting hair and nails, accompanying patient for monthly treatment, registering the social undesirables for the returning process, cleaning rooms, monitoring the condition of the social undesirables and other activities according to patient needs. Regional Technical Implementation Unit Social Shelter Keputih Surabaya place on Keputih Tegal No. 32. It is an institution for giving social welfare services, fostering, and empowering the social undesirables. The social undesirables consists of people with mental disorders, street children, beggars, prostitutes, and shemale. The entire patients at Regional Technical Implementation Unit Social Shelter Keputih in August 2018 were 1.245 people, and 985 were dominated by people with mental disorders. However the number of social undesirables facilitators at Regional Technical Implementation Unit Social Shelter Keputih were 21 people. It showed that between workers and social undesirables was imbalanced because ideal ratio between social workers and social undesirables was 1:10 (Social Welfare Data and Information Center, 2012). Based on Haryanti, Aini and Purwaningsih (2013), the number of nurses which imbalanced with the number of patients resulted increase workload. Nurses who had a high workload tend to suffered moderate stress $(85.2 \%)$. To produce effective and efficient services the availability of the number of nurses with patients must be appropriate.

Based on identifying problem, the writer is interested to analyze the relationship between individual characteristics and workload toward occupational stress level of social undesirables facilitators at Regional Technical Implementation Unit Social Shelter Keputih Surabaya.

Based on the background of the study, the writer identified the individual characteristics (consist of age, sex, education level, and working period), measured the workloads (physical and mental workload), and analyzed the relationship between individual characteristics and workload toward occupational stress level of social undesirables facilitators at Regional Technical Implementation Unit Social Shelter Keputih Surabaya. The writer then obtained the result of factors causing occupational stress.

\section{METHODS}

This research used a descriptive research which conducted using the observational method. The writer of the study used a cross-sectional 
method. The respondents of this research used total population workers of social undesirables facilitators at Regional Technical Implementation Unit Social Shelter Keputih Surabaya which is up to 21 workers. The research was held in August to September 2018.

The independent variables were individual characteristics (age, sex, education level, and working period) and workload (physical and mental workload). The dependent variable in this study was the occupational stress level.

The data was obtained through interviewing facilitators, measuring, and distributing the questionnaire. The writer obtained the data of individual characteristics variables (age, sex, education level, and working period) from respondents identity data through the questionnaire. The writer obtained the variable of physical workload measurement from Indonesian National Standard (SNI) 7269:2009 based on the level of calories needed according to energy expenditure. The variable of mental workload was obtained from the National Aeronautics \& Space AdministrationTask Load Index (NASA-TLX) questionnaire. The variable of occupational stress was obtained from the Health and Safety Executive (HSE) questionnaire (Tarwaka, 2013).

The writer analyzed the data for obtaining the result of frequency distribution of individual characteristics, workload measurement, and occupational stress level of the facilitators. The writer did a statistic test for revealing the relationship between independent and dependent variables. The writer used the contingency coefficient for analyzing variables relation.

\section{RESULT}

\section{Individual Characteristics}

Individual characteristics consist of age, sex, education level, and working period. As presented in the Table 1, Individual characteristics of social undesirables facilitators at Regional Technical Implementation Unit Social Shelter Keputih Surabaya were dominated by facilitators of 36-45 years old $(47.6 \%), 76.2 \%$ of the facilitators were male, around $57.1 \%$ of the facilitators had the education level in Senior High School (SMA). In addition, there were $52.4 \%$ of the facilitators had $\leq 3$ years of working period and included the new working period category.

\section{Workload}

Social undesirables facilitator has the main occupation to giving social service for social undesirables. They have responsibilities for helping patients doing their Activities of Daily Living (ADL) such as bathing, preparing meals, cleaning leftover food, cutting hair and nails, accompanying patient for monthly treatment, providing medicine, and other activities. Furthermore, social undesirables facilitators have responsibility for handling individual cases, empowering the social undesirables, and had to be ready for unexpected events. Based on the workload measurement results in table 2 there were $76.2 \%$ facilitators had moderate physical workload and $81 \%$ facilitators had a high mental workload.

\section{Occupational Stress}

Based on the occupational stress result in Table 3 using Health and Safety Executive (HSE) questionnaire, there were mostly $52.4 \%$ facilitators had a low level of occupational stress, $42.9 \%$ of the facillitators at a moderate level and only $4.8 \%$ of the facilitators had a high level of occupational stress. The different individual characteristics will lead to different stress responses.

Table 1. The Frequency Distribution of Individual Characteristics of Social Undesirables Facilitators at Regional Technical Implementation Unit Social Shelter Keputih Surabaya in 2018

\begin{tabular}{ccc}
\hline Variable & Frequency (n) & Percentage (\%) \\
\hline Age (Yeears) & 3 & 14.3 \\
$17-25$ & 7 & 33.3 \\
$26-35$ & 10 & 47.6 \\
$36-45$ & 1 & 4.8 \\
$46-55$ & & \\
Sex & 16 & 76.2 \\
Male & 5 & 23.8 \\
Female & & \\
\hline Education Level & 5 & 23.8 \\
Elementary & 3 & 14.3 \\
Junior High School & 12 & 57.1 \\
High School & 1 & 4.8 \\
Diploma & & \\
\hline Working Period & 10 & 47.6 \\
$>3$ years & 11 & 52.4 \\
3 y years & &
\end{tabular}


Table 2. The Frequency Distribution of Workload of Social Undesirables Facilitators at Regional Technical Implementation Unit Social Shelter Keputih Surabaya in 2018

\begin{tabular}{ccc}
\hline Variable & Frequency (n) & Percentage (\%) \\
\hline Physical Workload & & \\
Moderate & 16 & 76.2 \\
High & 5 & 23.8 \\
\hline Mental Workload & & \\
Moderate & 4 & 19 \\
High & 17 & 81 \\
\hline
\end{tabular}

Table 3. The Frequency Distribution of Occupational Stress Level of Social Undesirables Facilitators at Regional Technical Implementation Unit Social Shelter Keputih Surabaya in 2018

\begin{tabular}{ccc}
\hline Occupational Stress & Frequency (n) & Percentage (\%) \\
\hline Low & 11 & 52.4 \\
Moderate & 9 & 42.9 \\
High & 1 & 4.8 \\
\hline
\end{tabular}

\section{Age and Occupational Stress}

The result of the study showed 10 facilitators $(47.6 \%)$ were categorized in $36-45$ years old. Based on the cross-tabulation in Table 4, there were facilitators in 17-25 years old had occupational stress in low, moderate, and high level with each category percentage of $33.3 \%$. Most of the facilitators in 26-35 years old had moderate occupational stress (71.4\%). Most of 36-45 years old facilitators (70\%) had a low level of occupational stress, and only one facilitator had low occupational stress. The statistic data showed the contingency coefficient between age and occupational stress was 0.572 . It signified that age had a moderate relationship to occupational stress.

\section{Sex and Occupational Stress}

The result of the study showed 16 facilitators were male $(76.2 \%)$. Based on the cross-tabulation in Table 5 , most of the male facilitators $(50 \%)$ and female facilitators $(60 \%)$ had a low level of occupational stress. Based on the statistical measurement, the contingency coefficient between sex and occupational stress level was 0.136 . It signified that sex had a weak role in causing occupational stress.
Table 4. Cross Tabulation Data between Age and Occupational Stress of Social Undesirables Facilitators at Regional Technical Implementation Unit Social Shelter Keputih Surabaya in 2018

\begin{tabular}{ccccccc}
\hline \multirow{2}{*}{ Age } & \multicolumn{6}{c}{ Occupational Stress } \\
\cline { 2 - 7 } & \multicolumn{2}{c}{ Low } & \multicolumn{3}{c}{ Moderate } & \multicolumn{2}{c}{ High } \\
\cline { 2 - 7 } & $\mathbf{n}$ & $\mathbf{\%}$ & $\mathbf{n}$ & $\%$ & $\mathbf{n}$ & $\%$ \\
\hline $17-25$ & 1 & 33.3 & 1 & 33.3 & 1 & 33.3 \\
$26-35$ & 2 & 28.6 & 5 & 71.4 & 0 & 0 \\
$36-45$ & 7 & 70 & 3 & 30 & 0 & 0 \\
$46-55$ & 1 & 100 & 0 & 0 & 0 & 0 \\
\hline
\end{tabular}

Table 5. Cross Tabulation Data between Sex and Occupational Stress of Social Undesirables Facilitators at Regional Technical Implementation Unit Social Shelter Keputih Surabaya in 2018

\begin{tabular}{cccccccc}
\hline \multirow{2}{*}{ Sex } & \multicolumn{6}{c}{ Occupational Stress } \\
\cline { 2 - 8 } & \multicolumn{2}{c}{ Low } & \multicolumn{3}{c}{ Moderate } & \multicolumn{2}{c}{ High } \\
\cline { 2 - 8 } & $\mathbf{n}$ & $\mathbf{\%}$ & $\mathbf{n}$ & $\mathbf{\%}$ & $\mathbf{n}$ & $\mathbf{\%}$ \\
\hline Male & 8 & 50 & 7 & 43.8 & 1 & 6.3 \\
Female & 3 & 60 & 2 & 40 & 0 & 0 \\
\hline
\end{tabular}

\section{Education Level and Occupational Stress}

The result of the study showed 12 facilitators $(57.1 \%)$ had a high school education level. Based on the cross-tabulation in Table 6 , most of the facilitators who had primary school $(80 \%)$ and secondary school $(66.7 \%)$ education level suffered occupational stress at a low level. Moreover, the facilitators from high school $(50 \%)$ and diploma $(100 \%)$ level had moderate occupational stress. The value of the contingency coefficient between the education level and occupational stress was 0.398 . This coefficient signified that the level of education had a low relationship for causing occupational stress.

\section{Working Period and Occupational Stress}

Based on the result of the study, 11 facilitators $(52.4 \%)$ had the working period $\leq 3$ years. As presented in the Table 7, most of the facilitators with the working period $>3$ years had a moderate level of occupational stress. The value of the contingency coefficient between working period and occupational stress of the facilitators was 0.298 . The coefficient 
Table 6. Cross Tabulation Data between Education Level and Occupational Stress of Social Undesirables Facilitators at Regional Technical Implementation Unit Social Shelter Keputih Surabaya in 2018

\begin{tabular}{ccccccc}
\hline \multirow{2}{*}{ Education Level } & \multicolumn{6}{c}{ Occupational Stress } \\
\cline { 2 - 7 } & \multicolumn{2}{c}{ Low } & \multicolumn{3}{c}{ Moderate } & \multicolumn{2}{c}{ High } \\
\cline { 2 - 7 } & $\mathbf{n}$ & $\mathbf{\%}$ & $\mathbf{n}$ & $\mathbf{\%}$ & $\mathbf{n}$ & $\mathbf{\%}$ \\
\hline SD & 4 & 80 & 1 & 20 & 0 & 0 \\
SMP & 2 & 66.7 & 1 & 33.3 & 0 & 0 \\
SMA & 5 & 41.7 & 6 & 50 & 1 & 8.3 \\
Diploma & 0 & 0 & 1 & 100 & 0 & 0 \\
\hline
\end{tabular}

Table 7. Cross Tabulation Data between Working Period and Occupational Stress of Social Undesirables Facilitators at Regional Technical Implementation Unit Social Shelter Keputih Surabaya in 2018

\begin{tabular}{ccccccc}
\hline \multirow{2}{*}{ Working Period } & \multicolumn{6}{c}{ Occupational Stress } \\
\cline { 2 - 7 } & \multicolumn{2}{c}{ Low } & \multicolumn{3}{c}{ Moderate } & \multicolumn{2}{c}{ High } \\
\cline { 2 - 7 } & $\mathbf{n}$ & $\boldsymbol{\%}$ & $\mathbf{n}$ & $\boldsymbol{\%}$ & $\mathbf{n}$ & $\boldsymbol{\%}$ \\
\hline$>3$ years & 6 & 60 & 3 & 30 & 1 & 10 \\
$\leq 3$ years & 5 & 45.4 & 6 & 54.5 & 0 & 0 \\
\hline
\end{tabular}

showed a low relationship between working period and occupational stress level.

\section{Physical Workload and Occupational Stress}

Physical workload measurement used Indonesian National Standard (SNI) 7269:2009 based on the level of calories needed according to energy expenditure. Based on the result of the physical workload measurement, there were 16 facilitators $(76.2 \%)$ who had a moderate level of physical workload.

As presented in the Table 8, most of the facilitators who had moderate physical workload $(56,3 \%)$ suffered occupational stress at a low level. In other hands, most of the facilitators who had high physical workload $(60 \%)$ suffered occupational stress at moderate level. The number of contingency coefficient between physical workload and occupational stress was 0.209 . It revealed the low relationship between physical workload and occupational stress.

\section{Mental Workload and Occupational Stress}

Mental workload measurement used National Aeronautics \& Space Administration-Task Load
Table 8. Cross Tabulation Data between Physical Workload and Occupational Stress of Social Undesirables Facilitators at Regional Technical Implementation Unit Social Shelter Keputih Surabaya in 2018

\begin{tabular}{ccccccc}
\hline \multirow{2}{*}{$\begin{array}{c}\text { P y s i c a l } \\
\text { Workload }\end{array}$} & \multicolumn{4}{c}{ Occupational Stress } \\
\cline { 2 - 7 } & \multicolumn{2}{c}{ Low } & \multicolumn{3}{c}{ Moderate } & \multicolumn{3}{c}{ High } \\
\cline { 2 - 7 } & $\mathbf{n}$ & $\mathbf{\%}$ & $\mathbf{n}$ & $\mathbf{\%}$ & $\mathbf{n}$ & $\mathbf{\%}$ \\
\hline Moderate & 9 & 56.3 & 6 & 37.5 & 1 & 6.3 \\
High & 2 & 40 & 3 & 60 & 0 & 0 \\
\hline
\end{tabular}

Table 9. Cross Tabulation Data between Mental Workload and Occupational Stress of Social Undesirables Facilitators at Regional Technical Implementation Unit Social Shelter Keputih Surabaya in 2018

\begin{tabular}{ccccccc}
\hline \multirow{2}{*}{$\begin{array}{c}\text { e n t a } \\
\text { Workload }\end{array}$} & \multicolumn{4}{c}{ Occupational Stress } \\
\cline { 2 - 7 } & \multicolumn{2}{c}{ Low } & \multicolumn{3}{c}{ Moderate } & \multicolumn{2}{c}{ High } \\
\cline { 2 - 7 } & $\mathbf{n}$ & $\mathbf{\%}$ & $\mathbf{n}$ & $\mathbf{\%}$ & $\mathbf{n}$ & $\mathbf{\%}$ \\
\hline Moderate & 4 & 100 & 0 & 0 & 0 & 0 \\
High & 7 & 41.2 & 9 & 52.9 & 1 & 5.9 \\
\hline
\end{tabular}

Index (NASA-TLX) questionnaire showed that there were 17 facilitators $(81 \%)$ who had a high level of mental workload.

As presented in the Table 9, all facilitators with a moderate level of mental workload suffered occupational stress at the lower level. Furthermore, most workers with a high mental workload suffered moderate occupational stress $(52.9 \%)$. The value of the contingency coefficient between mental workload and occupational stress was 0.420 . It referred that mental workload had a moderate relation toward occupational stress level.

\section{DISCUSSION}

\section{Age and Occupational Stress}

Social undesirables facilitators at Regional Technical Implementation Unit Social Shelter Keputih Surabaya were mostly at the age of 36-45 years old (47.6\%). When people get older, they will get difficulty in using their senses, differentiating things, and remembering memories. Therefore, age is a considered factor to get a job.

The result of the study indicated that age and occupational stress had a moderate level. The results of cross tabulation show that the more 
age increases the stress level will decrease. This condition is not similar to what Anoraga (2009) stated that the more people got older, the more stress they had in doing the job. In addition, he argued when people got older they would face complex problems. Based on the interview with the employers at Regional Technical Implementation Unit Social Shelter Keputih Surabaya, the writer obtained the result that elderly facilitators were able to handle the social undesirables, especially when they had temper tantrums. The elderly facilitators had more experiences than the youngers. The more people get older, the more experiences they have. As a consequence, most of the elderlies were able to overcome their problems in the workplace and got easier for handling stress.

\section{Sex and Occupational Stress}

Based on the statistical data analysis, the writer obtained the result that sex had a very low relationship toward occupational stress. Abdurrahman and Sulaksmono (2013) in her research stated that sex and occupational stress were not correlated with each other.

Sex which was compared to gender, did not have a great impact in causing occupational stress. According to Sasongko (2008), gender is a term used in differentiating role, job, status, and responsibility between male and female. Furthermore, gender is a social construction, it is able to change from one to other generations. Social construction differentiates males and females into masculinity and femininity. Femininity is associated with emotional and sensitive, while masculinity is associated with brave, independent, and decisive. Wu and Shih (2010) stated that gender differences (masculine and feminine) affect the level of stress. Furthermore, Wu explained that gender differences had a significant influence in causing occupational stress rather than sex differences. People with masculine personality were able to handle their stress rather than people with feminine personality.

Abdurrahman and Sulaksmono (2013) argued that it could not be ascertained yet that one of the sexes affected the level of occupational stress. Moreover, the level of the individual stress could also be measured from social and cultural contexts.

The results of the study were not in accordance with Lestari, Wahyuni and Ekawati (2015) that argue there was a relationship between sex and occupational stress on wardens of class IIA Women in Semarang. Sex affects the condition of men and women. Women's muscle abilities tend to be more tired than men and there is a menstrual cycle in women that can affect physical and psychological conditions, especially while working. Furthermore, female workers who was getting married, there is a dual role that must be taken so that it can influence the occurrence of stress.

\section{Education Level and Occupational Stress}

Education is the process of learning, acquiring knowledge, and developing skill. In the globalization era, people must have a high educational background through formal or informal education. The development of advanced technology must be balanced with a reliable work capacity in order to fulfill the job demands. Based on the result of the study, the writer obtained the result that the education level had a low impact in causing occupational stress. Abdurrahman and Sulaksmono (2013) in his research disproved that the education level influenced occupational stress.

The purpose of education is to explore an individual's knowledge and paradigm. Setyawati (2010) argued that the higher the level of education, the easier for someone to think broadly. Through education, people's initiatives are increased and more efficient to finish their task in order to minimize the stress.

The education level of the social undesirables facilitators had a low impact in causing occupational stress. This condition was caused by the characteristics of the job. Social undesirables facilitator is a social service oriented occupation. It gives more priorities in practical services rather than theoretical knowledge. Skill improvement in providing services can be obtained by training, workshops, and other non-formal education activities. In consequence, Regional Technical Implementation Unit Social Shelter Keputih Surabaya does not set the minimum level of education for those who apply as social undesirables facilitators.

\section{Working Period and Occupational Stress}

Working period is the period of time that a person spends at paid labor. The period of working period in this study ranged from the facilitators' beginning of work until the research is finished. Handoko (2010) classified working period into 2 categories, namely old working period category and new working period category. The old category 
is a working period in more than 3 years. The new category is a working period in $\leq 3$ years.

Based on the result of the study, the writer obtained the result that working period has a low impact in causing occupational stress. This condition was different Ratih and Suwandi (2013), she stated that working period and occupational stress were correlated with each other. Moreover, the employers who had an old category of working period tended to suffer occupational stress. Long working period can lead employers to get stress.

According to the interview with the social undesirables facilitators at Regional Technical Implementation Unit Social Shelter Keputih Surabaya, they needed time to adapt at the beginning of their jobs in handling the unpredictable behaviour of the social undesirables. Some of the new facilitators, who were not able to adapt to the occupation, preferred to quit the job.

However, if those facilitators were able to adapt, they could handle and fix the problems which caused stress. It was also similar to the facilitators with an old-category of working period. The long working period did not always cause occupational stress. The social undesirables facilitators with a long working period had known how to treat and handle the social undesirables because they had adapted for years. The working period was correlated with experience and understanding of working. Abdurrahman and Sulaksmono (2013) stated that an employer, who had worked in the same field for a long time, had a great opportunity in surviving the problems because he had been able to adapt.

\section{Physical Workload and Occupational Stress}

Physical workload is the burden that body receives due to doing physical work. Physical workload measurement used Indonesian National Standard (SNI) 7269: 2009 based on the level of calories needs according to energy expenditure. Based on the measurement of the physical workload, majority facilitators had moderate physical workload.

Social undesirables facilitators in Regional Technical Implementation Unit Social Shelter Keputih Surabaya have responsibilities for helping doing Activities of Daily Living (ADL) such as bathing, helping to wear clothes, preparing meals, distributing meals, providing medicine, preparing medicine based on the the prescription given, providing fruits, cutting hair and nails, accompanying treatment, registering the social undesirables for the returning process, cleaning rooms, and monitoring the condition of the social undesirables.

Aside from helping doing Activities of Daily Living (ADL), facilitators had to be ready for unexpected events. The unexpected events such as there was a female patient with mental disorder escaped from the religious activity, there was patient who rebelled to take a bath, and patient tried to escape from social shelter, that made the facilitator ran to catch the patient. Another example was when the patient in emergency situation and died, the facilitators also involved in the funeral process. Several of social undesirables facilitators had their own motivation and spiritual understanding in doing jobs although they have various work activities that different from the work generally. They felt that the ones who actually helped were not the facilitators yet the social undesirables who actually helped the facilitators.

In this study, physical workload had a low impact in causing occupational stress. This result was consistent with Ibrahim, Amansyah and Yahya (2016), he argued that there was no relationship between physical workload and occupational stress. In some activities, the workers at Regional Technical Implementation Unit Social Shelter Keputih Surabaya worked together to complete the job without looking at the job duties, whether they were nurses, janitors, or security officers. Most of the facilitators had understood that the job demands were greater than the number of available resources. Coordination and teamwork ability could minimize the workload and decrease occupational stress. Everyone has different responses and effects of stress. According to Tarwaka (2013), stress could become a negative thing when it wasn't controlled and would cause health disorders, decrease performance, efficiency, until decrease work productivity. In contrast, stress could become a positive thing when it was properly controlled.

The results of the study was different with Ratih and Suwandi (2013), she stated that physical workload influenced in causing occupational stress. Workload which is whether too low or high leads to occupational stress. Based on the concept of ergonomic, the task demands should not be too excessive and must be in accordance with work capacity. According to Tarwaka (2013) the task demands that are too high can cause excessive energy use, which can lead to overstress. Whereas the workload that is too low will cause bored and lead to understress. 


\section{Mental Workload and Occupational Stress}

Mental workload is a work activity that involves more thoughts and feelings. The social undesirables in Regional Technical Implementation Unit Social Shelter Keputih Surabaya consists of people with mental disorders, street children, beggars, prostitutes, and shemale. They had different behaviour and facilitators must give treatment as patients needed. The facilitators had to be aware if there was a patient who obtained tantrums (explosive emotions, noisy, and over nervous) because Regional Technical Implementation Unit Social Shelter Keputih Surabaya was dominated by people with mental disorders. Facilitators often felt some unpleasant treatments such as being grabbed, beaten, and spit upon by the social undesirables with mental disorders. The facilitators had to monitor the condition of the social undesirables and had to be ready to face every situation. Special treatment was needed in order to prevent commotion and quarrel at the location.

One of the facilitator activities of social undesirables is to provide mental and non-mental medicine. When giving medicine, facilitators need to pay close attention so that the medicine was not given to the wrong person. These activities require high accuracy and concentration, especially the number of social undesirables served is numerous.

According to measurement of the mental workload used National Aeronautics \& Space Administration-Task Load Index (NASA-TLX) questionnaire, majority facilitators had a high mental workload. Based on the statistical measurement, the writer obtained the result that mental workload had a moderate impact in causing occupational stress. This condition was similar to the research conducted by Fahamsyah (2017) at the Installation of the Central Steril Supply Department (CSSD) of Surabaya Hajj General Hospital which mental workload and occupational stress were correlated with each other. Workload should be appropriate to the work capacity of the person who does the job. According to Tarwaka (2013), workload would cause occupational stress. Even though mental activity seems lighter than physical work activity, it has heavier responsibility than physical activity because it involves the work of brains than working muscles (Tarwaka, 2013). The social undesirables facilitators needed both physical and mental strength to overcome problems in their jobs. The over mental workload would cause both physical and mental fatigue, and cause occupational stress.

\section{CONCLUSION}

The conclusion of this study is the factors of individual characteristics, namely age and mental workload have a moderate relationship in causing occupational stress. In contrast, other factors such as sex, education level, working period, and physical workload have a low relationship in causing occupational stress. The suggestions are by doing refreshing, decorating the workplace, giving a reward to increase passion in working, and enhancing more employers, especially facilitators who have competency standards as social workers. Thus, the number of more employers creates a proper work capacity toward workload and prevents occupational stress.

\section{ACKNOWLEDGEMENT}

The writer would like to thank all of the employers who have a good cooperative work at Regional Technical Implementation Unit Social Shelter Keputih Surabaya during the research. The writer also would like to address her biggest gratefulness to the research advisor, Mr. Mulyono for his kindness to assist and guide during research writing.

\section{REFERENCES}

Abdurrahman, M. and Sulaksmono, M. (2013) 'Hubungan Karakteristik Individu dan Shift Kerja dengan Stres Kerja (Studi pada Agent Contact Center PLN 123 PT. PLN (Persero) Distribusi Jawa Timur Site Surabaya Tahun 2013)', The Indonesian Journal of Occupational Safety and Health, 2(2), pp. 137-144.

Anoraga, P. (2009) Psikologi kerja. Jakarta: Rineka Cipta.

Fahamsyah, D. (2017) 'Analisis Hubungan Beban Kerja Mental dengan Stres Kerja', The Indonesian Journal of Occupational Safety and Health, 6(1), pp. 107-115.

Handoko, T. H. (2010) Manajemen Personalia \& Sumberdaya Manusia. 2nd edn. Yogyakarta: BPFE UGM.

Haryanti, Aini, F. and Purwaningsih, P. (2013) 'Hubungan antara Beban Kerja dengan Stres Kerja Perawat di Instalasi Gawat Darurat RSUD 
Kabupaten Semarang', Jurnal Managemen Keperawatan, 1(1), pp. 48-56.

Hasan, A., Wahyuni, I. and Kurniawan, B. (2018) 'Hubungan antara Beban Kerja Mental dan Shift Kerja Terhadap Stres Kerja pada pekerja Central Control Room (Studi Kasus pada PT. PJB Unit Pembangkit Paiton Probolinggo)', Jurnal Kesehatan Masyarakat (e-Journal), 6(4), pp. 255-260.

Ibrahim, H., Amansyah, M. and Yahya, G. N. (2016) 'Faktor - Faktor yang Berhubungan dengan Stres Kerja pada Pekerja Factory 2 PT . Maruki Internasional Indonesia Makassar', Al-Sihah :Public Health Science Journal, 8(1), pp. 60-68.

Lestari, B. S. A., Wahyuni, I. and Ekawati (2015) 'Hubungan Karakteristik Individu dan Komunikasi Interpersonal dengan Stres Kerja pada Petugas Penjagaan (Sipir) di Lembaga Pemasyarakatan (Lapas) Klas IIA Wanita Semarang', Jurnal
Kesehatan Masyarakat (e-Journal), 3(3), pp. 326-332.

Ratih, Y. and Suwandi, T. (2013) 'Analisis Hubungan antara Faktor Individu dan Beban Kerja Fisik dengan Stres Kerja di Bagian Produksi PT $\mathrm{X}$ Surabaya', The Indonesian Journal of Occupational Safety and Health, 2(2), pp. 97-105.

Sasongko, S. S. (2008) Konsep dan Teori Gender. Jakarta: Center for Gender Training and Women's Quality Improvement.

Setyawati, L. (2010) Selintas Tentang Kelelahan Kerja. Yogyakarta: Amara Books.

Tarwaka (2013) Ergonomi Industri: Dasar-Dasar Pengetahuan Ergonomi dan Aplikasi di Tempat Kerja. Solo: Harapan Press.

Wu, Y. and Shih, K. (2010) 'The Effects of Gender Role on Perceived Job Stress', The Journal of Human Resource and Adult Learning, 6(2), pp. 74-79. 